\title{
THE RISK OF LOSING DESERTED MEDIEVAL RURAL SETTLEMENTS: OPPORTUNITIES FOR AGROTURISM AND RURAL DEVELOPMENT
}

\author{
Daniel E. May ${ }^{1}$
}

Received 3 June 2020, Revised 23 October 2020, Accepted 24 October 2020

\begin{abstract}
A significant number of deserted medieval rural settlements have been identified in Europe. These sites are at risk of disappearance as a consequence of current urban development and cropping intensification implying that relevant features of the cultural landscape informing about past rural traditions in the European countryside may be lost. The objective of this article is to illustrate this fact by means of a case study consisting of a deserted medieval rural upland settlement in Wales. A field walk carried out in this site revealed that old rural traditions and past ways of living can be identified from its own bodily engagement with the surrounding landscape. This evidence is used to argue that strategies that involve personal experience of deserted medieval rural settlements such as agroturism may be implemented to protect these sites and the cultural information contained in them.
\end{abstract}

Keywords: Deserted Medieval Rural Settlements; Field Walk; Rural Traditions in the European Countryside; Agroturism

\section{Introduction}

Traditionally, agriculture has been associated with a productive role consisting of producing food and fibre. However, this view has changed over the last decades and now it is recognised the multifunctional nature of this activity in terms of offering non-productive services that are associated with positive externalities (Bianchi, 2018; Rizzo, 2016; Śpiewak, 2016). That is, agriculture is seen today as an activity that plays important economic, social and environmental functions that contributes in addressing challenges such as food security, poverty alleviation, environmental protection and social welfare (Losch, 2004; Van Huylenbroek et al., 2007).

Agriculture has also been attached a function of preserving cultural landscapes and heritage (Renting et al., 2009; Vecco, 2010). However, it appears that this function has not properly been reinforced by current policy initiatives because there is evidence revealing a risk of loss of cultural landscapes in several European countries as a consequence of urbanisation and cropland intensification (Schulp et al., 2019). Apparently, this phenomenon is explained by lack of knowledge and awareness of the significant amount and value of cultural material contained in rural landscapes.

1 Dr. Daniel E. May. Kellogg daniel.maymontana@kellogg.ox.ac.uk

College, University of Oxford, United Kingdom; e-mail: 
A particular type of cultural heritage that seems to be in risk corresponds to deserted medieval rural settlements which are common archaeological remains in European countries (see for example Hejcman et al., 2013; Renes, 2015; Simms, 1976). These sites contain invaluable information of past European traditions in the countryside implying that their destruction as a consequence of current developments can cause a severe cultural loss.

The objective of this article is to provide evidence of potential loss of deserted medieval rural settlements by using as a case study a deserted medieval rural upland settlement in Wales, a type of settlement that is not yet fully understood. The article also discusses the role of tourism as a potential strategy to protect deserted medieval rural settlements and to bring rural development from adding value to cultural heritage in rural landscapes.

The article is organised as follows. Section 2 describes the development of the research on deserted medieval settlements in the UK and the current state of the knowledge in this area. This information is used to provide the context for the particular research on medieval rural upland settlements in Wales, a topic that is revised in Section3. Section 4 describes the site that was selected as a case study to show the potential of settlements of this nature to inform about past rural European traditions. Section 5 presents the results of a field walk recognition carried out in this site. Section 6 provides an assessment of the site based on the field walk and shows how its existence is in risk as a consequence of development and agricultural intensification. Finally, Section 7 concludes the paper.

\section{The Research on Medieval Settlements in the UK}

During the medieval period people in rural areas of Britain used to live in different types of permanent settlements ranging from individual farms to larger villages, and temporary abodes linked to upland grazing activities. A significant number of these settlements have survived as earthworks mainly in rural areas (English Heritage 2011). In spite of this extensive evidence, people before the 1950s were sceptical about the existence of deserted settlements (Rowley and Wood 2000), and clear interest in the study of these settlements started in the 1950s when the Deserted Medieval Village Research Group was established (Hurst 1971; Taylor 2010). As the name of this group suggests, the research at that time was focused mainly on the study of deserted medieval villages and the research questions that where addressed by archaeologist were when and why these settlements were deserted (English Heritage 2011).

Available evidence has revealed that the phase of village desertion started in the early fourteenth century and continued until the fifteenth century (Dyer 1982; Rowley and Wood 2000). Initial explanations for this phenomenon were that village desertion was caused by the Black Death, warfare, famine and population declining (Postan 1950; Beresford 1971; Dyer 1994; McLeman 2011). Explanations arguing that some settlements declined in response to the appearance of more attractive villages in terms of available resources were also proposed (see for example Barley 1957). Today, it is known that deserted villages declined as a consequence of a more wide variety of social, cultural, economic, climatic, and catastrophic factors that not only include the reasons given above, but also depopulation to make way for sheep pasture given the prosperity of the wool industry; make profits from pasture agriculture; reorganisation of farms; abandonment of poor land; internal problems; and climatic downturn, among others (Dyer 1982; Rowley and Wood 2000; Dyer 2010; English Heritage 2011). In this context, it is argued that it is not possible to identify a single cause of village desertion because settlements were abandoned at different times and different circumstances implying that each particular place has its own history that demands individual investigation (Dyer 2010; English Heritage 2011).

In the 1970s, it was realised that deserted medieval villages are in reality a subset of a wider variety of settlements and a basic classification of deserted medieval settlements emerged (Taylor 2010; English Heritage 2011). According to this classification, deserted settlements can be classified into two groups, namely: nucleated settlements (i.e. relatively large and compact villages located mainly in the midland and northern counties of England); and dispersed settlements (i.e. hamlets and single farms located mainly in the northern and western uplands) (Jones and Page 2003; English Heritage 2011). In recognising this difference, the research was extended to include all types of settlements, a fact that is reflected in the transformation of 
the Deserted Medieval Village Research Group into the Medieval Settlement Research Group in 1986 (Rowley and Wood 2000; Silvester 2010).

\section{The research on deserted rural settlements in Wales}

The research on upland rural settlements in Wales is marginal in relation to the research on nucleated settlements (Roberts 2006). For example, near a thousand sites were recorded in Gwynedd in the 1990s, but only eight were excavated at the beginning of the XXI century without conclusive results (Thomson and Yates 2000). Nonetheless, some existing studies have revealed interesting facts about these sites.

Firstly, upland rural settlements in Wales are located mainly in moorland and rough pasture with little sign of human habitation today, little historical evidence of human occupation and lack of relationship between place-names and the origins of these settlements. The land in these places is considered as marginal from an agricultural point of view, and is only able to sustain a subsistence economy (Silvester 2010). Secondly, buildings in deserted rural settlements are typical $6 \mathrm{~m}$ to $15 \mathrm{~m}$ long by $4 \mathrm{~m}$ to $9 \mathrm{~m}$ wide. They can be isolated or appear in groups between two to six buildings. Some of them may be associated with an ovoid or D-shaped enclosure, and less often they are associated with field systems (Thomson and Yates 2000; Longley 2006). Thirdly, the interior of sites that have been investigated have produced little artefactual or structural evidence. However, pottery obtained from excavations carried out in different sites across Wales have revealed that rural settlements came into existence from year 1250 to year 1450 approximately, although some settlement were still occupied in the sixteenth century (Silvester 2010). Fourthly, it has been argued that the desertion process of upland rural settlements in Wales is explained by the Black Death, climatic factors, political tension and warfare in the borders (e.g. the Glyndwr's rebellion in the early fifteenth century). These factors, although different in nature, are relatively similar to those that explain the abandonment of large villages in lowland England (see Postan 1950; Barley 1957; Beresford 1971; Dyer 1982; Rowley and Wood 2000; Dyer 1994; Dyer 2010; English Heritage 2011; McLeman 2011). The exception is given by the transition from arable to pastoral, which was marginal in explaining the desertion in Wales because sheep pasture was already established by the time of Cistercians (Butler 1971). Finally, existing partial evidence have revealed that some of the deserted rural settlements were seasonal settlements (i.e. hafoday) with a role of transhumance, and others were permanently occupied by farmsteads (Bulter 1971; Silvester 2010).

The information described in this section reveals that the upland rural settlements in Wales are storages of a significant amount of rich information about rural traditions that have not fully been explored yet. In order to assess the potential of this type of sites to inform about past traditions, the following case study is considered.

\section{The case study: a Deserted Rural Settlement in North Wales}

The site considered in this article corresponds to a deserted rural settlement located in the community of Llangurig in Montgomeryshare, in the south face of the Rhiwlas Hill (grid reference: SN9307877521). According to the Royal Commission on the Ancient and Historical Monuments of Wales (2014a), this site was discovered in 1992 during RCAHMV aerial recognisance and corresponds to well preserved earthworks consisting of the remains of a building accessed via a track which crosses a wider set of earthen enclosures in direction NWSE. The dwelling is surrounding by an elongated 8-shaped enclosure with wider polygonal and rectangular field enclosures extending west and east. The whole site is contained within a more recent polygonal field enclosure which may be linked to the Enclosure-Period (Figure 1). 


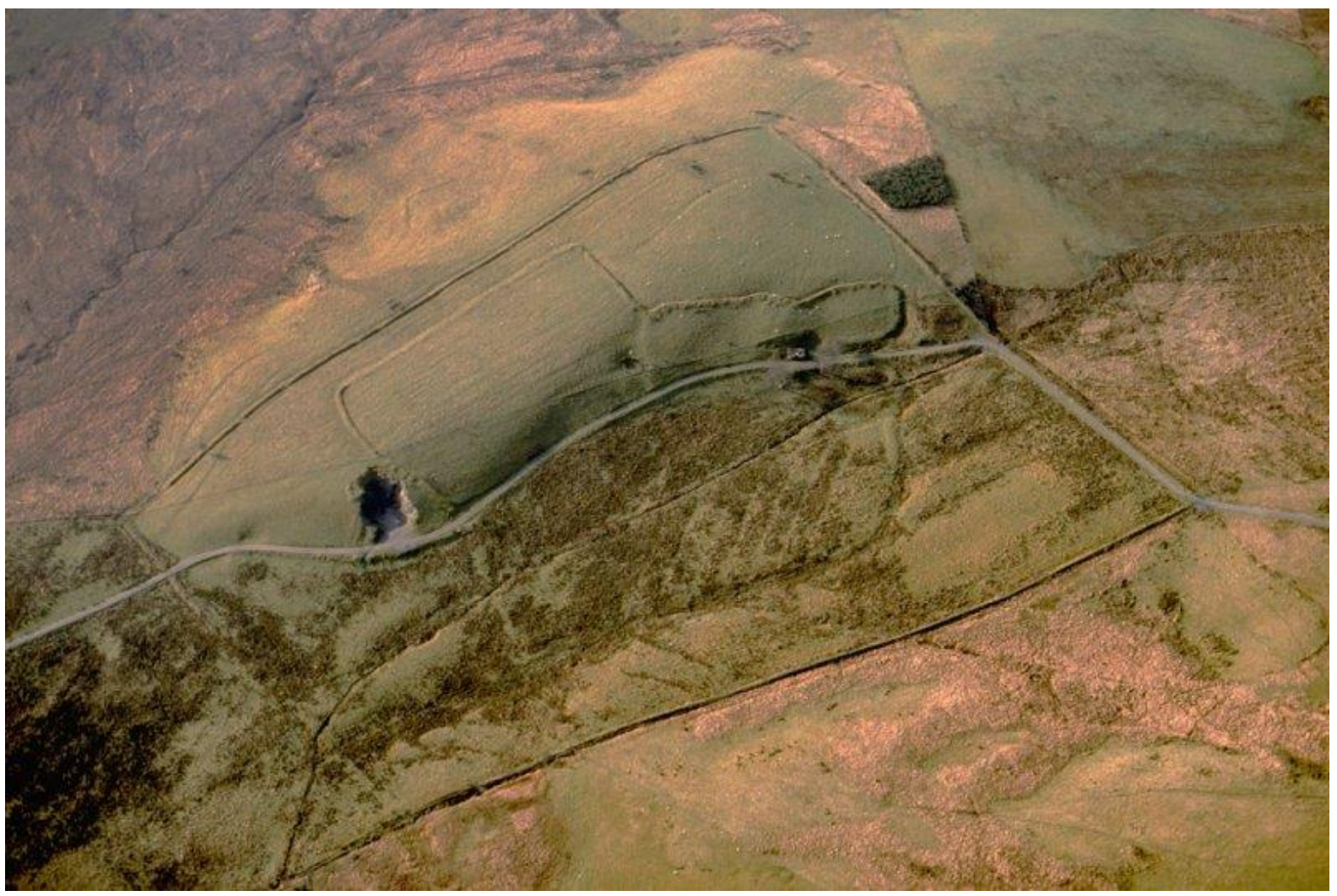

Fig 1. Deserted Rural Settlement, CWM Y Season, Rhiwlas Hill. Source: Royal Commission on the Ancient and Historical Monuments of Wales 2014a

In terms of the geology of the site, the sedimentary bedrock formed approximately in the Silurian Period when the local environment was previously dominated by deep seas. This bedrock corresponds to Mudstone and Sandstone. These rocks were formed in deep seas from infrequent slurries of shallow water sediments which were then redeposited as graded beds (British Geological Survey 2014).

At the local scale, the deserted settlement under consideration is bounded by a number of hills that makes the site difficult to be seen from the surrounded area. For the same reason, visibility from the site is limited, a fact that was discovered from a field walk carried out on this place (see Section 5). It is not clear why the site was located in a place of this nature. Perhaps it was established in an area protected from the occurrence of other groups of people, or perhaps the local landscape has some resources that made this place attractive for the people who occupied this place. In any case, a valley located SE from the deserted rural settlement can be seen suggesting that this settlement was not fully isolated.

At the large scale, on the other hand, a number of deserted medieval sites are located in the surrounding area. It is interesting to notice that they are in general clustered near determined towns. This might suggest that these sites were in some way related to these towns. For the case of the deserted rural settlement under consideration, this site is located about $2 \mathrm{~km}$ from another deserted medieval settlement that consists of a platform $26 \mathrm{~m}$ long by $12 \mathrm{~m}$ wide with a D-shaped earthwork enclosure (Royal Commission on the Ancient and Historical Monuments of Wales $2014 \mathrm{~b})$. Both of them are located about $3 \mathrm{~km}$ from the Llangurig town. Given the proximity of these sites to the town, it might be the case that these sites were related to the history of Llangurig.

\section{Field walk}

In considering Figure 1, four areas/features of the deserted rural settlement under study were identified, namely: an 8-shaped enclosure; a rectangular field (i.e. Field 1); a polygonal field (i.e. Field 2); and an external enclosure. A draw showing these areas/features is presented in Figure 2. 


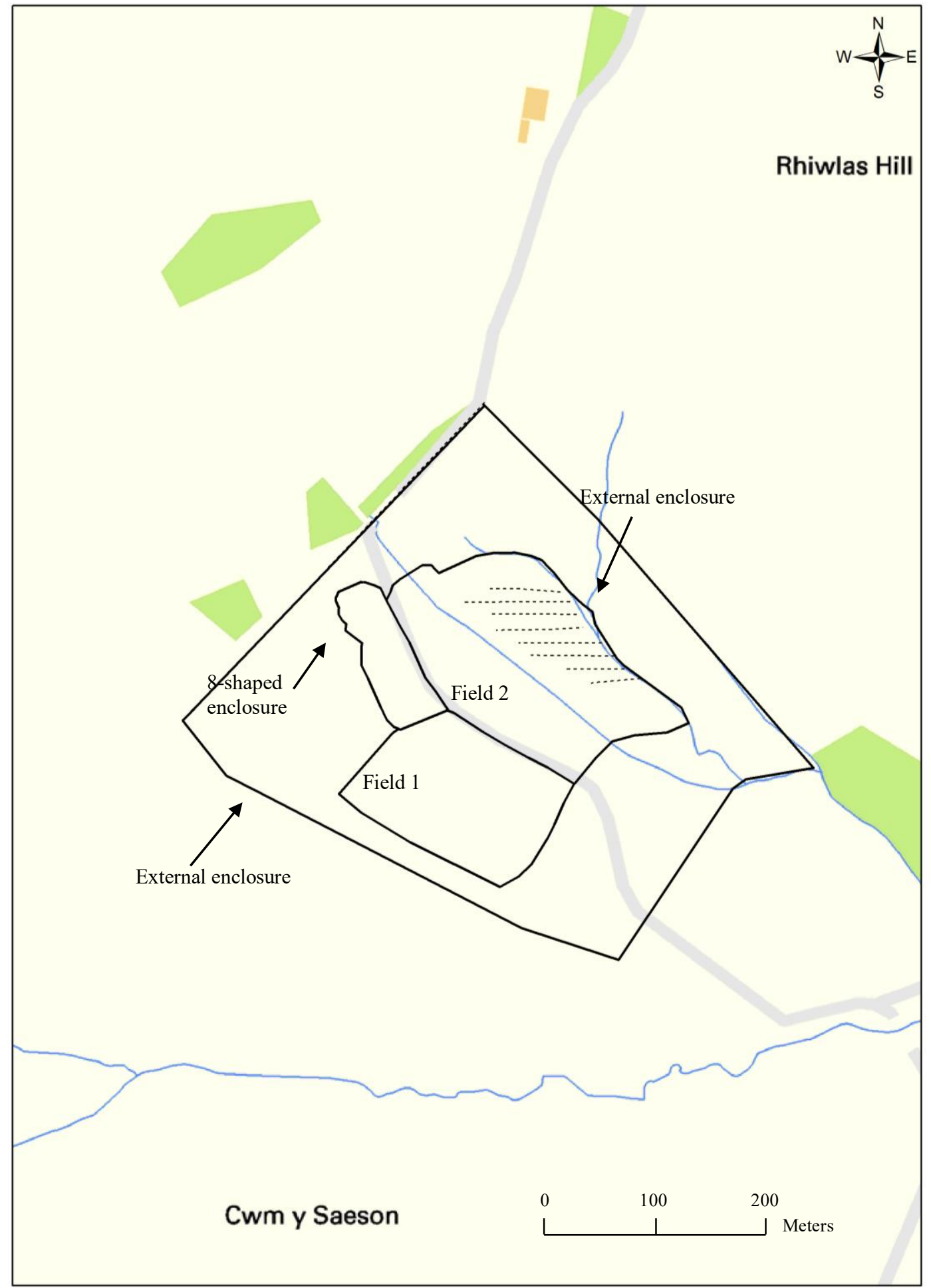

Fig 2. Distinctive areas/features of the site. Source: Developed by the author using OS Street View vector map (2014), grid references from UK Grid Reference Finder (2014), and ArcGis software

A field walk recognition was carried out with the purpose of gaining a better understanding of the site. The four areas/features presented in Figure 2 were visited. They are described as follows.

The 8-shaped enclosure presents an irregular platform with a prominent slope in direction NW$\mathrm{SE}$. The dimension of the enclosure is about $123 \mathrm{~m}$ long by $46 \mathrm{~m}$ wide (dimension estimated using UK Grid Reference, 2014). There is no clear evidence of building remains on the ground. However, there is an earthwork in one side of the platform with some holes on the top (Figure 3). This structure may be the remains of building foundations, but it may also be the east boundary 
of the enclosure given its long extension. Because no obvious evidence of the building mentioned by the Royal Commission on the Ancient and Historical Monuments of Wales (2014a) was found, it is suggested that the site was altered since it was discovered in 1992, a fact that was confirmed by the owner of the farm. On the other hand, the edge of the east part of the enclosure presents holes of unknown nature, and the north top edge of the platform ends in the form of a sharp structure. It is not clear whether this part of the platform corresponds to a building remain, or the top edge of the enclosure.

The Field 1 has a rectangular shape $152 \mathrm{~m}$ by $113 \mathrm{~m}$ wide approximately (dimension estimated using UK Grid Reference, 2014). It is located south from the 8-shaped enclosure and presents a sharp slope descending in NW-SE direction (Figure 4). The earthworks show in Figure 1 that define the enclosure of this field has been destroyed in several parts. This again shows that the site has strongly been disturbed since it was discovered in 1992. Nonetheless, parts of the earthworks have survived in some areas of the field, mainly in the top and bottom edges of this field (Figure 5).

The Field 2 has a polygonal shape approximately $200 \mathrm{~m}$ long by $121 \mathrm{~m}$ wide on average (dimension estimated using UK Grid Reference, 2014). It is located east from the 8-shaped enclosure. This field is relatively flat without evidence of earthworks defining its edges. It presents water courses in some areas, a fact that is consistent with the model developed in Figure 2. This field is crossed by tenuous parallel lines that may be the remains of medieval ridges and furrows or some related earthworks probably used to manage water (see Figures 1 and the discontinuous lines in Figure 6). These lines were only identified when the Field 2 was observed from a relative high altitude (Figure 6).

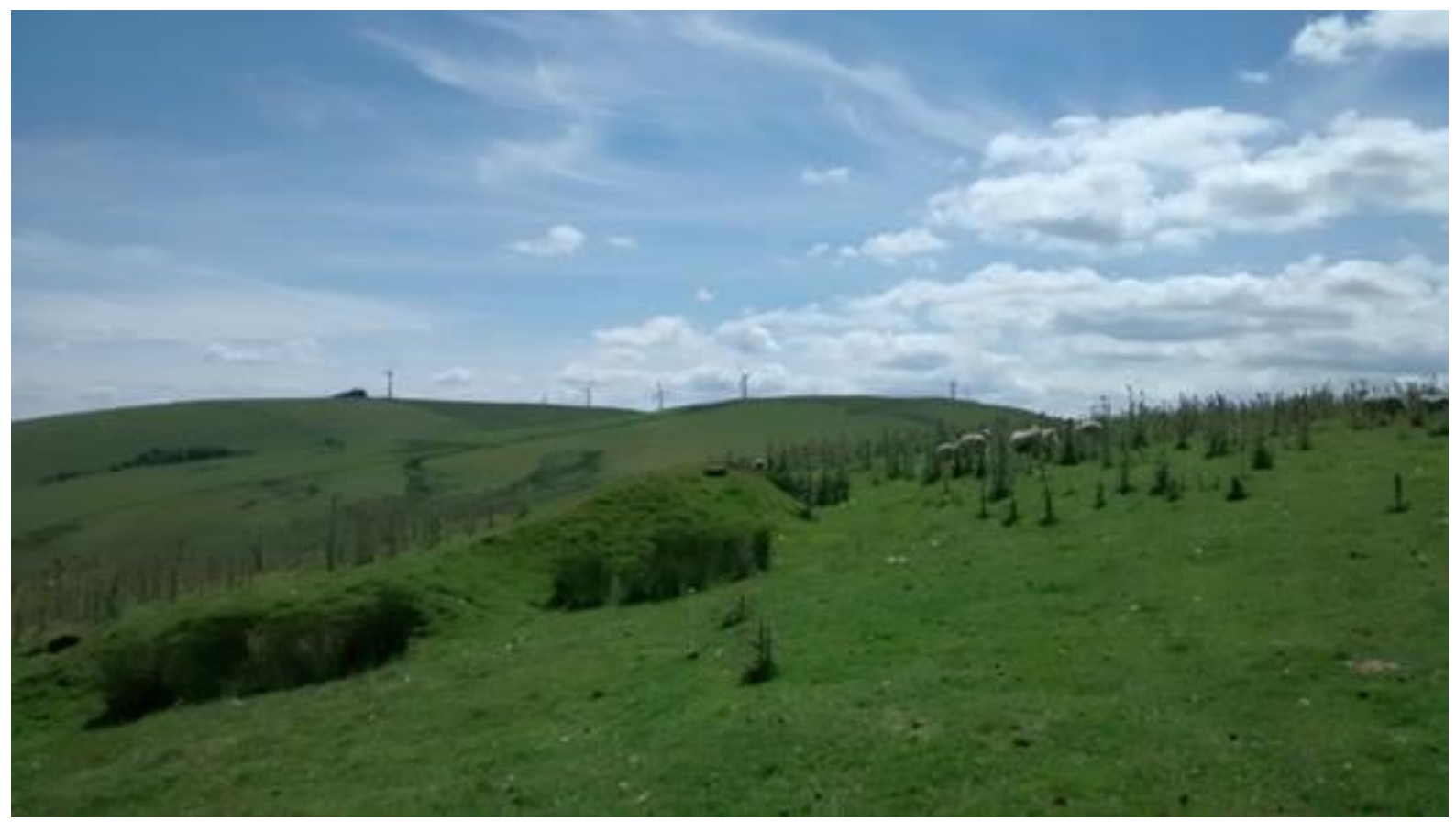

Fig 3. Platform in the 8-shaped enclosure (right) with earthwork (left). 


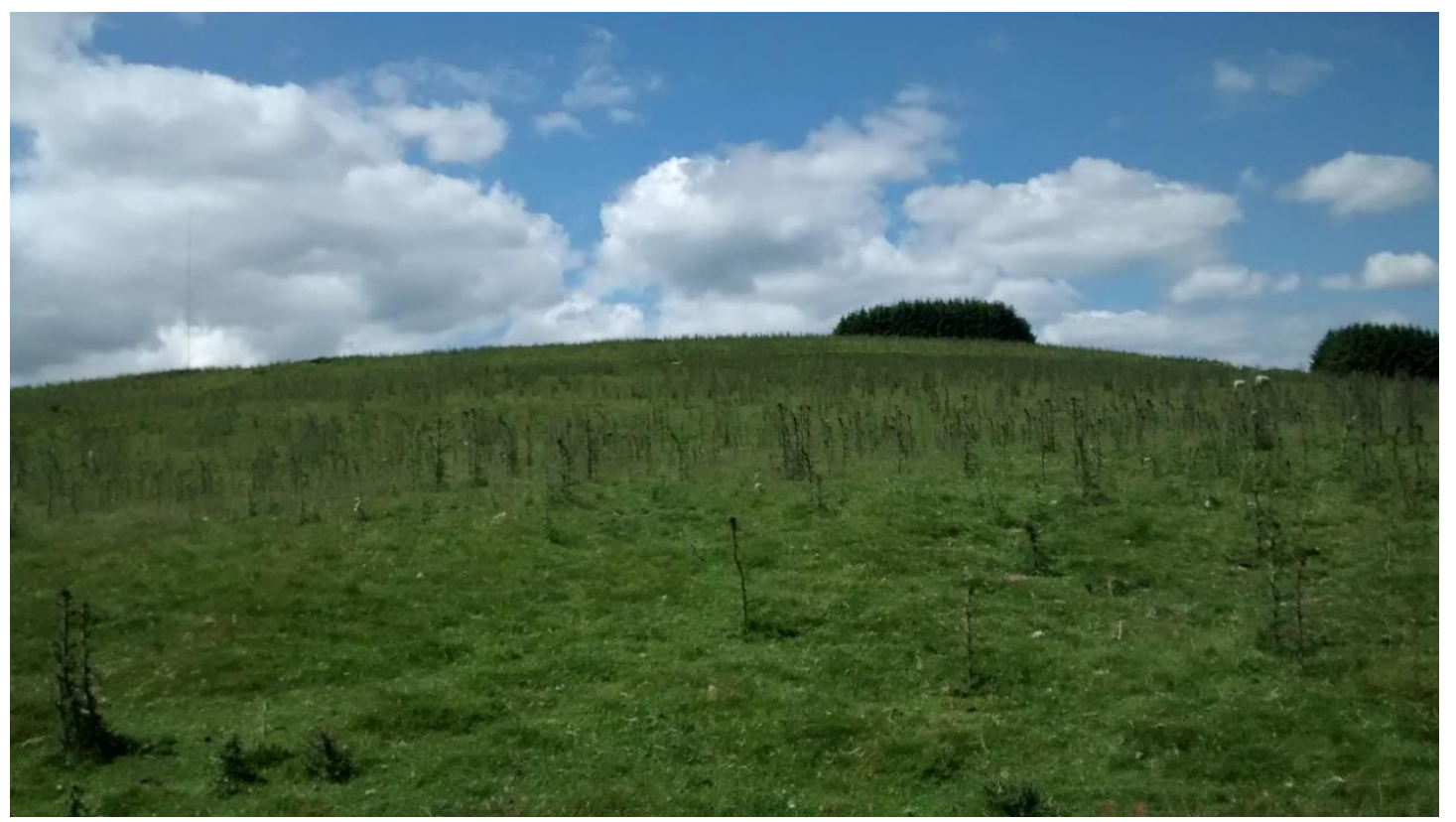

Fig 4. The Field 1.

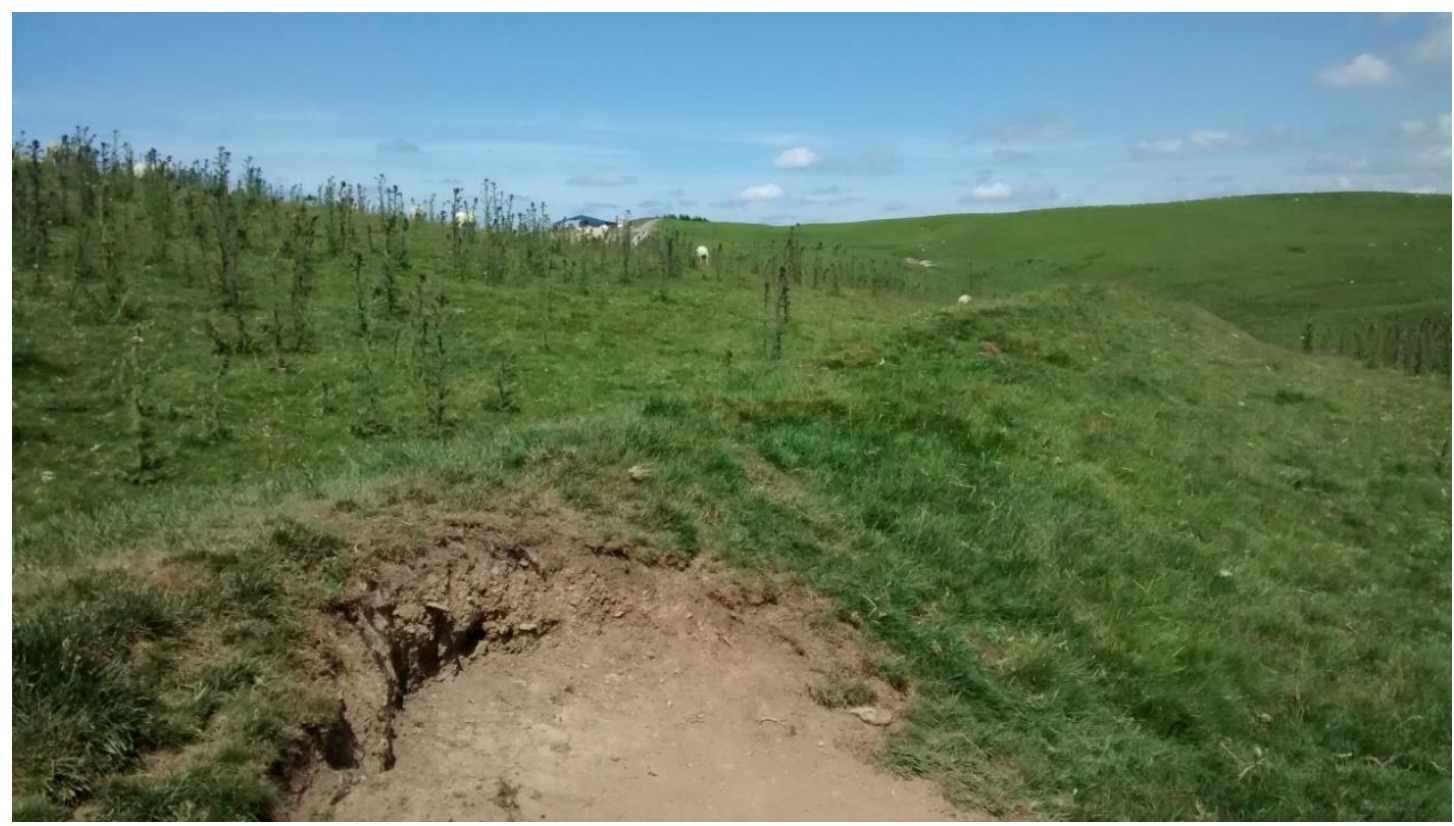

Fig 5. Bottom edge of Field 1. 


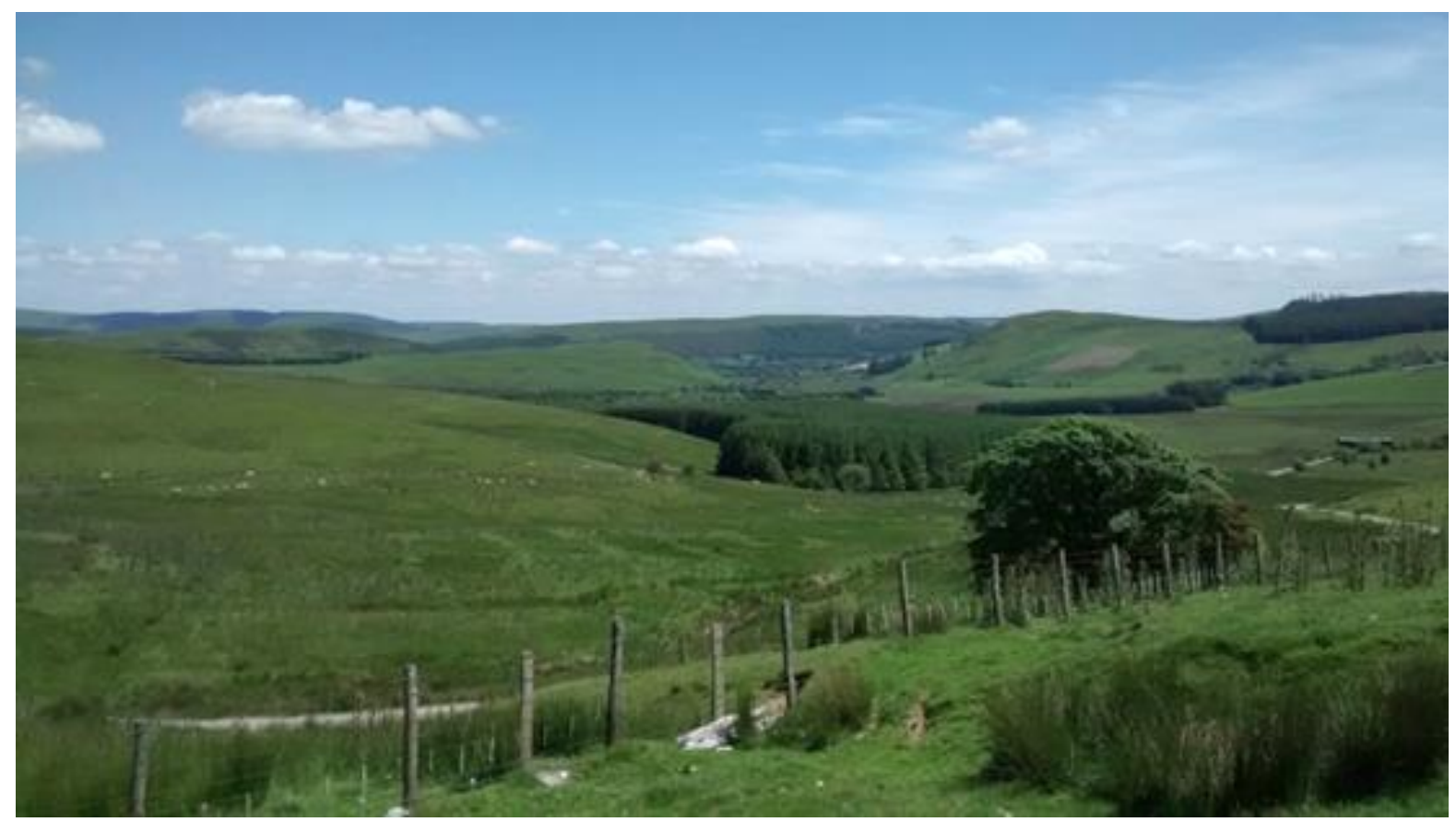

Fig 6. Parallel lines in Field 2 (middle of the picture).

Finally, the external enclosure has a polygonal shape approximately $380 \mathrm{~m}$ long by $318 \mathrm{~m}$ wide on average (dimension estimated using UK Grid Reference, 2014). The earthworks that define the edges of this enclosure are preserved in good conditions (Figure 7). They present postholes in the top located relatively at regular intervals in two lines. An interesting characteristic of the earthwork that defines the bottom edge of the enclosure is that it is different from the rest of the earthworks because it is composed of stones (Figure 8). This is a distinctive feature of this part of the external enclosure.

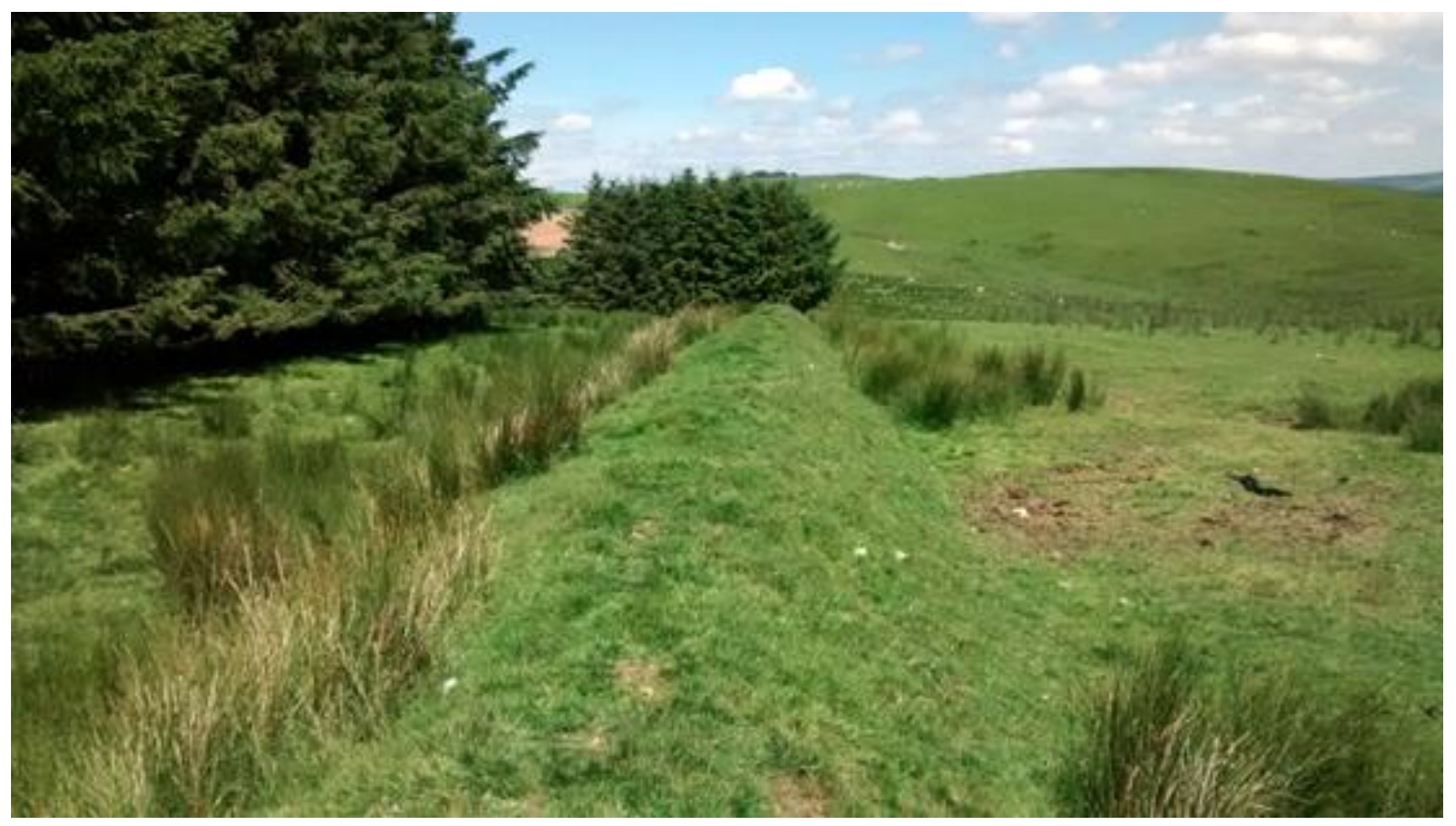

Fig 7. Top edge of the external enclosure. 


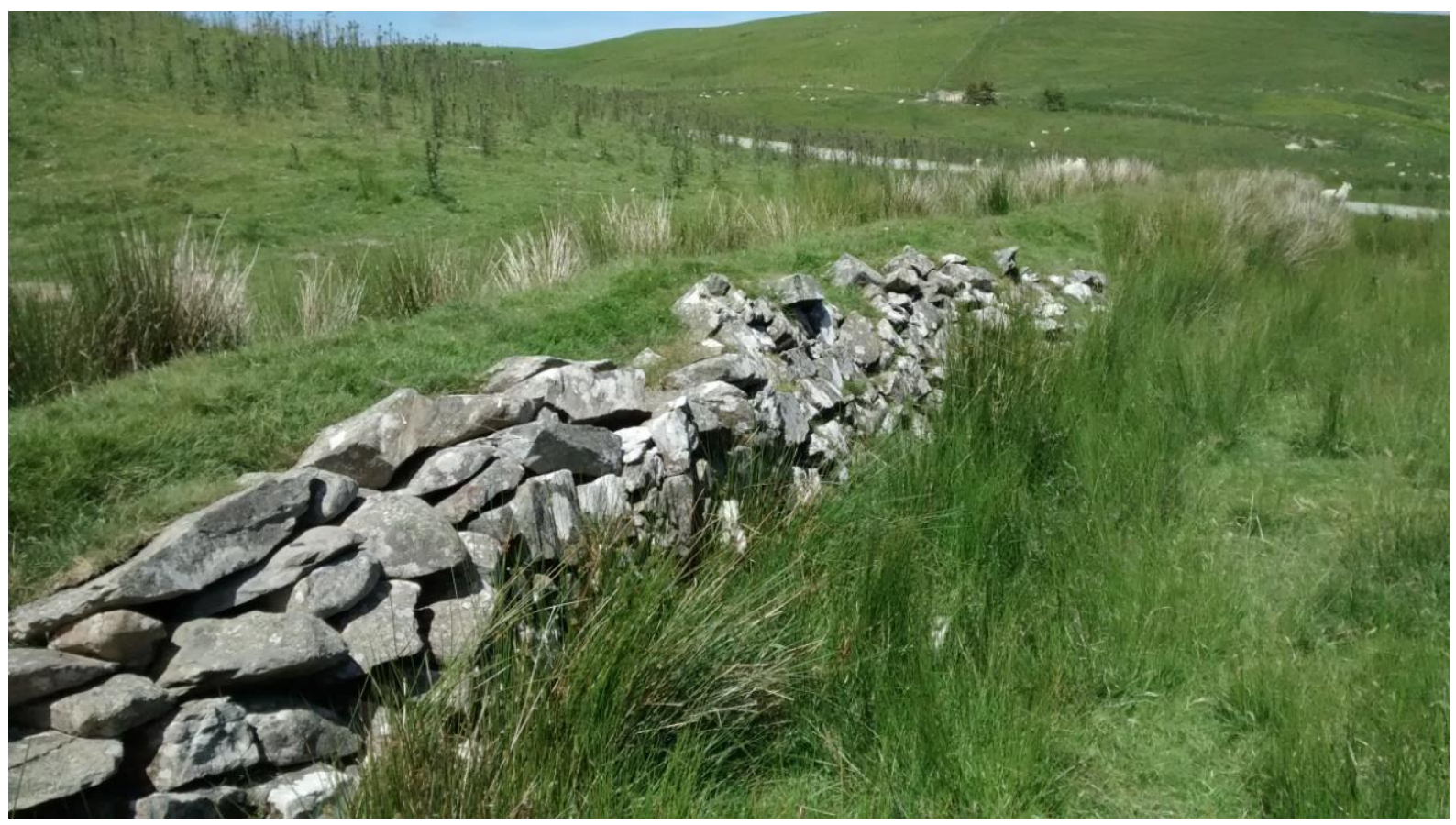

Fig 8. Bottom edge of the external enclosure.

\section{Assessment of the Site}

The information provided in the previous sections was used to carry out the following assessment of the deserted rural settlement under study.

At the large scale, this site form part of a complex of deserted settlements across Montgomeryshire, a fact that is consistent with the observation made by Thomson and Yates (2000). This implies that the existence of deserted settlements in this area was a common phenomenon. What is not clear, however, is whether the site under study is contemporary to the other sites and whether it is related to the Llangurig town. In relation to this point, it is interesting to mention that a detailed historical book of Llangurig was written by Hamer and Lloyd (1875). This book is focused mainly on family successions in Llagurig, but no mention to rural settlements in the past is made. What is known, however, is that this area was ruled by the Normans, a fact that is inferred from silver coins associated with King Henry I discovered around the town (Hamer and Lloyd, 1875) and the history of the Llangurig parish church which, according to the Diocese of Bangor (2014), was controlled by the Cistercian monks from 1164. This evidence linked to the fact that deserted settlements in Wales came into existence from 1250 until 1450 (Silvester, 2010) suggests that the site under study was probably a Norman innovation. Nonetheless, lack of historical record makes it impossible to know the specific time when this settlement was established and the reason for its abandonment.

At the local scale, the site is located in a place with low visibility. It is not clear why people at that time made this choice. Perhaps this reflects a number of factors including the possibility that Montgomeryshire was a place of permanent tension between England and Welsh rulers and the available local resources such as water. The latter is evident in Field 2 suggesting that this field was suitable for the development of some sort of agriculture.

In terms of the deserted settlement itself, it looks like a complex managed site composed of different parts that may be contemporary or perhaps they correspond to extensions made at different periods of time. As pointed out above, the Royal Commission on the Ancient and Historical Monuments of Wales (2014a) explains that the 8-shaped enclosure is the place of a dwelling that was not identified during the field walk. Even though, this information is used to argue that this enclosure was the place where buildings were constructed, a choice that seems reasonable given the configuration of the site. Given the large extension of this enclosure, it is possible that it contained a group of buildings rather a single one. This is because current evidence has revealed that buildings in deserted rural villages in Wales are $6-15 \mathrm{~m}$ long by $4 \mathrm{~m}-$ 
9m wide and in some sites they appear in groups (Silvester, 2010). The Field 1, on the other hand, seems to be a place suitable for grass and sheep pasture. The reason is because water is not available in this part of the field and also because its high slope. The surviving earthworks that form the edges of this field were probably barriers used to contain animals in this area of the site. The Field 2 seems to be appropriate for agricultural production. The reason is because this area of land is relatively flat and is crossed by water courses. This may explain why earthworks that resemble ridges and furrows are presented in this field. Finally, the evidence obtained from the field walk suggests that the external enclosure was apparently used to enclose the whole site by means of posts. It is interesting to notice that the earthwork that forms the bottom edge of this enclosure is different in composition. The reason for this change in composition is unknown, but it may be a type of structural reinforcement. According to the Royal Commission on the Ancient and Historical Monuments of Wales (2014a), the external enclosure is a posterior extension because it is better preserved than the other parts of the site. An alternative interpretation is that this enclosure is more prominent because it was probably used as a sort of protective barrier.

As revealed by this assessment, the site is rich in features informing about past rural traditions and ways of living in this landscape such as farming practises, exploitation of the surrounding landscape, and rural building traditions, among others. Unfortunately, this important information can be lost because the current local landscape has signs of developments that might put in danger the site if they continue their advancement towards the settlement (Figure 9). One of them correspond to wind turbines located south from the site, and the other is a ploughed area of land located next to the site.

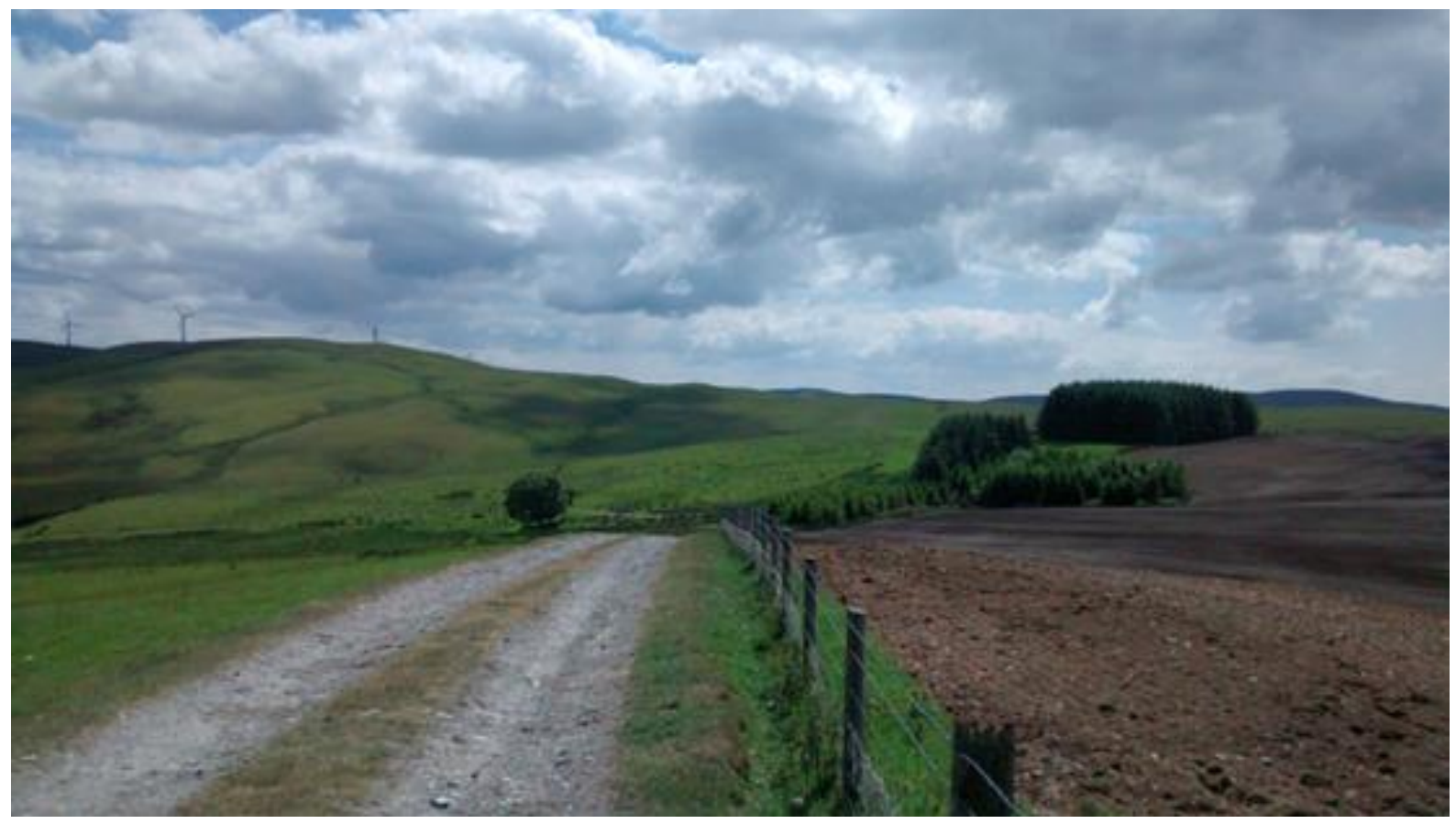

Fig 9. Deserted settlement in the middle of the picture, wind turbines at the far end, and ploughed land on the right.

A possible strategy that may be adopted to prevent this loss is the use of tourism as a tool to protect sites of this nature and also to contribute in bringing rural development. The reason is because, as revealed by the field walk carried out in the selected site, bodily engagement and personal experience with the cultural landscape makes it possible to appreciate the value of the features contained in the landscape and gain a better understanding of the information that these features contain in terms of past traditions. Consequently, bodily experience by means of tourism has the potential to increase awareness and the perceived value of archaeological sites by people who are less familiar with some determined archaeological remains such as deserted medieval rural settlement. This, in turn, would increase the incentives to protect these sites.

This type of tourism is a form of agrotourism that can also contribute in bringing rural development. This is because it can be a tool for promoting diversification of economic practices in 
the countryside, maintaining farming activities, and preserving the environment and cultural landscapes (Neumeier and Pollermann, 2014; Kizos and losifides 2007). It can also benefit farmers by helping them to complement their income obtained from the farm by being involved in conservation initiatives, and by increasing recognition of the value of marginal rural areas (Mastronardi et al., 2017; Pérez et al., 2013).

\section{Conclusions}

There are a significant number of deserted medieval settlements in Europe that could be destroyed by current urban developments and cropping intensification. This is illustrated in this article by a case study consisting of a deserted medieval rural upland settlement in Wales which was explored by means of a field walk. This exercise revealed that this type of sites has the potential to inform about a significant and rich amount information related to past rural traditions in the countryside that can be identified from personal bodily engagement with the cultural landscape. In order to prevent the loss of this important information, it is argued in this article that agrotourim may be implemented as a tool to increase awareness and the perceived value of deserted mediaeval rural settlement by allowing people to experience the landscape of these sites. This not only would help to rescue sites that are in danger of disappearance, but also to promote rural development by adding value to rural landscapes and offering farmers a way to complement their income by means of economic diversification.

It is important to highlight the fact that this article is based on a phenomenological approach suggesting that some of the patterns identified in the deserted medieval settlements may be biased (for a discussion, see Bruck, 2005; Fleming, 2006; Tilley, 2008). Alternative non-invasive approaches that could be adopted to verify some of these patterns are topographic survey, geophysical survey, and LiDAR, among others. This could be complemented with an analysis of material culture remains in order to gain a better understanding of the nature of the site. All these possible extensions are left for future research.

Academic references

[1] Barley, M. W. (1957). Cistercian Land Clearance in Nottinghamshire: Three Deserted Villages and Their Moated Successor. Nottingham Medieval Studies 1, 75-89. DOI: $10.1484 / J . N M S .3 .444$.

[2] Beresford, M. W. (1971). A Review of Historical Research (to 1968). In Beresford, M. \& Hurst, J. G., eds., Deserted Medieval Villages (pp. 3-75). London: Lutterworth Press.

[3] Bianchi, R. (2018). Multifunctionality in Agriculture. New Productive Paths in the Primary Sector. Journal of Agriculture and Life Sciences 5(2), 1-7. DOI: 10.30845/jals.v5n2p1.

[4] Bruck, J. (2005). Experience the past? The Development of a Phenomenological Archaeology in British Prehistory. Archaeological Dialogues 12(1), 45-72. DOI: $10.1017 /$ S1380203805001583.

[5] Bulter, L. A. S. (1971). The Study of Deserted Medieval Settlements in Wales (to 1968). In Beresford, M. \& Hurst, J. G., eds., Deserted Medieval Villages (pp. 249-269). London: Lutterworth Press.

[6] Dyer, C. (1982). Deserted Medieval Villages in the West Midlands. Economic History Review 35(1), 19-34. DOI: 10.1111/j.1468-0289.1982.tb01184.x.

[7] Dyer, C. (1994). The English Medieval Village Community and Its Decline. Journal of British Studies 33(4), 407-429. DOI: 10.1086/386063.

[8] Dyer, C. (2010). Villages in crisis: social dislocation and desertion, 1370-1520. In Dyer, C. \& Jones, R., eds., Deserted Villages Revisited (pp. 28-45). Hertfordshire: University of Hertfordshire Press. 
[9] Fleming, A. (2006). Post-processual Landscape Archaeology: a Critique. Cambridge Archaeological Journal 16(3), 267-280. DOI: 10.1017/S0959774306000163.

[10] Hamer, E. \& Lloyd, H.W. (1875). The history of the parish of Llangurig. Whitefish: Kessinger Publishing.

[11] Hejcman, H., Karlík, P., Ondráček, J. \& Klír, T. (2013). Short-Term Medieval Settlement Activities Irreversibly Changed Forest Soils and Vegetation in Central Europe. Ecosystems 16, 652-663. DOI: 10.1007/s10021-013-9638-3.

[12] Hurst, J. G. (1971). A Review of Historical Research (to 1968). In Beresford, M. \& Hurst, J.G., eds., Deserted Medieval Villages (pp. 76-144). London: Lutterworth Press.

[13] Jones, R. \& Page, M. (2003). Characterizing Rural Settlements and Landscape: Whittlewood Forest in the Early Middle Ages. Medieval Archaeology 47, 53-84. DOI: 10.1179/med.2003.47.1.53.

[14] Kizos, T. \& losifides, T. (2007). The Contradictions of Agrotourism Development in Greece: Evidence from Three Case Studies. South European Society \& Politics 12(1), 59-77. DOI: $10.1080 / 13608740601155443$.

[15] Longley, D. (2006). Deserted rural settlements in north-west Wales. In Roberts, K., ed., Lost farmsteads. Deserted rural settlements in Wales (pp. 61-82). London: Council of British Archaelogy. DOI: 10.5284/1081755.

[16] Losch, B. (2004). Debating the Multifunctionality of Agriculture: From Trade Negotiations to Development Policies by the South. Journal of Agrarian Change 4(3), 336-360. DOI: 10.1111/j.1471-0366.2004.00082.x.

[17] Mastronardi, L., Giaccio, V., Giannelli, A. \& Stanisci, A. (2017). Methodological proposal about the role of landscape in the tourism development process in rural areas: the case of Molise Region (Italy). European Countryside 9(2), 245-262. DOI: 10.1515/euco-2017-0015.

[18] McLeman, R. A. (2011). Settlement Abandonment in the Context of Global Environmental Change. Global Environmental Change 21S, S108-S120. DOI: 10.1016/j.gloenvcha.2011.08.004.

[19] Neumeier, S. \& Pollermann, K. (2014). Rural tourism as promoter of rural development prospects and limitations: case study findings from a pilot project promoting village tourism. European Countryside 6(4), 270-296. DOI: 10.2478/euco-2014-0015.

[20] Leco, F., Pérez, A., Hernández, J. M. \& Campón, A. M. (2013). Rural Tourists and Their Attitudes and Motivations Towards the Practice of Environmental Activities such as Agrotourism. International Journal of Environmental Research 7(1), 255-264. DOI: $10.22059 /$ IJER.2012.604.

[21] Postan, M. M. (1950). Some agrarian evidence of declining population in the late Middle Ages. Economic History Review 2(3), 221-246. DOI: 10.2307/2590120.

[22] Renes, H. (2015). Historic Landscapes Without History? A Reconsideration of the Concept of Traditional Landscapes. Rural Landscapes: Society, Environment, History 2(1), 2. DOI: 10.16993/rl.ae.

[23] Renting, H., Rossing, W. A. H., Groot, J. C. J., Van der Ploeg, J. D., Laurent, C., Perraud, D., Stobbelaar, D. J. \& Van Ittersum, M. K. (2009). Exploring multifunctional agriculture. A review of conceptual approaches and prospects for an integrative transitional framework. Journal of Environmental Management 90(S2), S112-S123. DOI: 10.1016/j.jenvman.2008.11.014.

[24] Rizzo, F. (2016). Approaching multifunctional by a 'normative vire': Finnish farmers' visions on contemporary agriculture. European Countryside 8(1), 16-32. DOI: 10.1515/euco-20160002.

[25] Roberts, K. (2006). The deserted rural settlement project: background and methodology. In Roberts, K., ed., Lost farmsteads. Deserted rural settlements in Wales (pp. 1-10). London: Council of British Archaelogy. DOI: 10.5284/1081755. 
[26] Rowley, T. \& Wood, J. (2000). Deserted Villages. London: Bloomsbury.

[27] Schulp, C. J. E. Levers, C., Kuemmerle, T., Tieskens, K. F. \& Verburg, P. H. (2019). Mapping and modelling past and future land use change in Europe's cultural landscapes. Land Use Policy 80, 332-344. DOI: 10.1016/j.landusepol.2018.04.030.

[28] Silvester, R. (2010). Abandoning the uplands: depopulation among dispersed settlements in western Britain, in Dyer, C. \& Jones, R., eds., Deserted Villages Revisited (pp. 140-161). Hatfield: University of Hertfordshire Press.

[29] Simms, A. (1976). Deserted medieval villages and fields in Germany, a survey of the literature with a select bibliography. Journal of Historical Geography 2(3), 223-238. DOI: 10.1016/0305-7488(76)90058-X.

[30] Śpiewak, R. (2016). Multifunctionality of organic farming: case study from Southern Poland. European Countryside 8(1), 1-15. DOI: 10.1515/euco-2016-0001.

[31] Taylor, C. (2010). The origins and development of deserted village studies. In Dyer, C. \& Jones, R., eds., Deserted Villages Revisited (pp. 1-7). Hatfield: University of Hertfordshire.

[32] Thomson, D. \& Yates, M. (2000). Deserted rural settlements in Wales - a framework for study, a strategy for protection. RURALIA III, Památky archeologické, Suppl. 14 (pp. 37-45).

[33] Tilley, C. (2008). Phenomenological Approaches to Landscape Archaeology, in David, B. \& Thomas, J., eds., Handbook of Landscape Archaeology (pp. 271-276). Walnut Creek, CA, Left Coast Press.

[34] Van Huylenbroek, G., Vandermeulen, V., Mettepenningen, E. \& Verspecht, A. (2007). Multifunctionality of agriculture: a review of definitions, evidence and instruments. Living Reviews in Landscape Research 1(3), 5-43. DOI: 10.12942//rlr-2007-3.

[35] Vecco, M. (2010). A definition of cultural heritage: From the tangible to the intangible. Journal of Cultural Heritage 11(3), 321-324. DOI: 10.1016/j.culher.2010.01.006.

Other sources

[36] British Geological Survey. (2014). Grid reference SN $93078 \quad 77521$. http://mapapps.bgs.ac.uk/geologyofbritain/home.html (accessed 27/02/2020).

[37] Diocese of Bangor (2014). Llangurig Parish Church. Llanidloes, Powys: St. Idloes Press.

[38] English Heritage (2011). Introduction to Heritage Assets: Medieval Settlements. English Heritage.

[39] OS Street View vector map. (2014). https://www.ordenancesurvey.co.uk (accessed 2/03/2020).

[40] Royal Commission on the Ancient and Historical Monuments of Wales. (2014a). Deserted Rural Settlement, CWM Y Season, Rhiwlas Hill. https://coflein.gov.uk/en/site/402060/details/deserted-rural-settlement-cwm-y-saesonrhiwlas-hill (accessed 25/01/2020).

[41] Royal Commission on the Ancient and Historical Monuments of Wales. (2014b). Foel Goch Deserted Rural Settlement https://coflein.gov.uk/en/site/410162/details/foel-goch-desertedrural-settlement (accessed 25/01/2020).

[42] UK Grid Reference Finder. (2014). http://www.gridreferencefinder.com/\# (accessed 05/02/2020). 